\title{
Altiplano F2007, nueva variedad de trigo para siembras de temporal*
}

\author{
Altiplano F2007, new wheat variety \\ for seasonal plantings
}

\begin{abstract}
Héctor Eduardo Villaseñor Mir ${ }^{1}$, Julio Huerta Espino ${ }^{1}$, Eduardo Espitia Rangel ${ }^{1 \S}$, Ernesto Solís Moya ${ }^{2}$, Leodegario Osorio Alcalá $^{3}$, Javier Ireta Moreno ${ }^{4}$ y Patricia Pérez Herrera ${ }^{1}$

${ }^{1}$ Campo Experimental Valle de México-INIFAP. Carretera Los Reyes-Texcoco, km 18.5. Coatlinchán, Texcoco, Estado de México, C. P. 56250. Tel. 015959212715. Ext. 161. ${ }^{2}$ Campo Experimental Bajío-INIFAP. Carretera Celaya-San Miguel de Allende, Celaya, km 6.5, Guanajuato. C. P. $38110 .{ }^{3}$ Campo Experimental Valles CentralesINIFAP. ${ }^{4}$ Campo Experimental Centro Altos de Jalisco, INIFAP. Carretera. Tepatitlán-Lagos de Moreno, km 8. Col. Rancho Las Cruces, Tepatitlán de Morelos, C. P. 47600, Jalisco, Jalisco. Tel. 01378782 46 38. Ext. 3017. ${ }^{\S}$ Autor para correspondencia: espitia.eduardo@inifap.gob.mx.
\end{abstract}

\section{Resumen}

La variedad Altiplano F2007 fue generada por el programa de Mejoramiento Genético de Trigo de Temporal del INIFAP con sede en el Campo Experimental Valle de México. Es una variedad dehábito de primavera que fue obtenida de una cruza simple y con la aplicación del método de selección familias masivas. Porte semi-erecto al amacollamiento y posee tallos tolerantes al acame. A inicios del espigamiento tiene una frecuencia alta de plantas con hoja bandera recurvada. En madurez sus espigas son de color claro, piramidales, laxas y de posición ligeramente curvada. Es de porte de planta intermedio y de ciclo de cultivo intermedio a tardío. Es resistente a moderadamente resistente a roya de la hoja y roya amarilla, y tolerante al complejo de enfermedades foliares. De 2005 a 2012 se experimentó en 121 sitios diferentes en temporales críticos (menos de $300 \mathrm{~mm}$ ), intermedios (300 a $600 \mathrm{~mm}$ ) y favorables (más de $600 \mathrm{~mm}$ ), y en las tres condiciones superó a las nueve variedades testigo de $7 \%$ hasta $24 \%$, observándose más ventaja en los temporales intermedios. Es una variedad que responde de manera consistente a medida que el ambiente de producción es mejor. Su grano es mediano, semiduro, de color blanco a ámbar, de alto peso hectolítrico, de gluten fuerte, balanceado y con buen volumen de pan, por lo que se clasifica dentro de los trigos del grupo 1, que es adecuado

\section{Abstract}

The variety Altiplano F2007 was generated by the Wheat Genetic Improvement Program of the INIFAP based in the Experimental Field Valley of Mexico. It is a variety of spring habit which was obtained from a single cross and the application of the method of selection massive families. Porte semi-erect and has to be tillering tolerant to lodging stalks. In early tasseling has a high frequency of plants with recurved flag leaf. At maturity its ears are light, pyramidal, loose and slightly curved position color. It is intermediate sized plant and cultivation cycle intermediate late. It is resistant to moderately resistant to leaf rust and stripe rust, and tolerant to foliar diseases complex. From 2005 to 2012 he experimented on 121 different sites at critical time (less than $300 \mathrm{~mm}$ ), intermediate (300 to 600 $\mathrm{mm}$ ) and favorable (over $600 \mathrm{~mm}$ ), and the three conditions surpassed the nine control varieties of $7 \%$ up to $24 \%$, with more intermediate seasonal advantage. It is a variety that performs consistently as the production environment is better. Its grain is medium, medium-hard, white to amber color, high test weight, strong gluten, balanced and with good bread volume, so it is classified in group 1 wheat, which is suitable for machine industry in the development of packaged bread or bread type roll, but is also suitable

\footnotetext{
* Recibido: noviembre de 2013

Aceptado: marzo de 2014
} 
para la industria mecanizada en la elaboración de pan de caja o pan tipo bolillo, sin embargo; también es adecuado para mezclas y corregir trigos de gluten suave o que sean tenaces. Se recomienda para su siembra en todas las áreas productoras de trigo de temporal en siembras tempranas a intermedias.

Palabras clave: rendimiento, tolerante al acame y resistencia a enfermedades.

La producción de trigo en México en el 2012 fue cercana a 4 millones de toneladas, registrándose un excedente de trigo macarronero de 500 mil toneladas y un déficit de trigo panificable que se importó de Estados Unidos de América principalmente(SIAP, 2013). En 1985 se produjo en Méxicola cosecharécord que fue de 5.4 millones de toneladas cosechadas en 1.2 millones de hectáreas (Villaseñor, 2000), de tal manera que en el país se tiene la experiencia y las condiciones para producir el trigo que actualmente se demanda (Fuente, 2008), incluso para algunas regiones en donde se produce trigo bajo riego con la calidad del grano importado (Peña, 2006). En los últimos 15 años la industria harinera de México importa anualmente aproximadamente $60 \%$ del trigo harinero que consume, cifra que en el 2012 fue cerca de 1.5 millones de toneladas (SIAP, 2013); ese trigo generalmente se producía en el noroeste de México; sin embrago, porla presenciadel carbón parcial, por la mayor productividad del trigo macarronero y porque el fleje del noreste al centro del país es muy alto para la industria molinera, se dejó de sembrar trigo harinero panificable (Villaseñor et al., 2008).

Las áreas temporaleras de México son una alternativa para producir el faltante de trigo harinero panificable, ya que en cerca de un millón de hectáreas es mejor opción que el maíz; sin embargo, en estas siembras el déficit hídrico, las enfermedades y las bajas temperaturas son las principales limitantes de la producción; así por ejemplo, tan sólo en lo que se refiere a las enfermedades, en la variedad Tlaxcala F2000 la roya amarilla junto con el tizón foliar le causan mermas en el rendimiento de hasta 30\% (Villaseñor et al., 2012), de tal manera que las variedades son un componente importante para lograr mayor productividad en siembras de temporal.

El Programa de Mejoramiento Genético de Trigo de Temporal del INIFAP, con sede en el CEVAMEX se inició en 1969 (Moreno y Villaseñor, 1993), desde ese tiempo ha trabajado durante los ciclos al año y ha liberado 20 variedades para siembras de temporal(Villaseñor et al.,2009).AltiplanoF2007 es una aportación más del programa de mejoramiento y cubre las necesidades para siembras de temporal. Por su adaptación for mixing and correct soft wheat gluten or are tenacious. It is recommended for planting in all wheat growing areas of seasonal plantings in early to intermediate.

Keywords: yield, tolerant to lodging and disease resistance.

Wheat production in Mexico in 2012 was close to 4 million tonnes, registering a surplus macaroni 500 thousand tons of wheat and bread wheat deficit that was imported from the United States primarily (SIAP, 2013). In 1985 the record harvest was 5.4 million tonnes harvested 1.2 million hectares (Villaseñor, 2000), so that the country has the experience and the conditions to produce wheat occurred in Mexico currently demand (Source, 2008), even for some regions where irrigated wheat is produced with quality imported grain (Peña, 2006). In the past 15 years the flour industry of Mexico annually imports about $60 \%$ of its wheat flour (Peña et al, 2008.), A figure that in 2012 was about 1.5 million tonnes (SIAP, 2013) that wheat usually was produced in northwestern Mexico, no clutch, by the presence of Karnal bunt by increased productivity of macaroni wheat and that the strip Northeast to the Midwest is very high for the milling industry, was allowed to plant breadmaking bread wheat (Villaseñor et al., 2008).

Rainfed areas of Mexico are an alternative to produce the missing bread wheat of bread-making, because in more than a million hectares is better choice than corn, but these crops in drought stress, disease and low temperatures are major production constraints, so for example, only in what they refer to diseases, variety Tlaxcala F2000 yellow rust with leaf blight will cause reductions in yield up to $30 \%$ (Villaseñor et al., 2012), such that the varieties are important for higher productivity in crops temporary component.

The Wheat Breeding Program of the INIFAP, located in CEVAMEX began in 1969 (Moreno and Villaseñor, 1993) since that time has worked for cycles per year and has released 20 varieties of seasonal plantings (Villaseñor et al., 2009). Altiplano F2007 is a contribution of the breeding program and meet the needs for seasonal plantings. By adapting and stability, this variety has been noted for its high yields compared with other varieties released for rainfed, so ranks as excellent choice for planting in all environments of rainfed wheat production in Mexico. Altiplano F2007 was obtained by hybridization and selection, using the method of massive families. 
y estabilidad, esta variedad ha destacado por sus altos rendimientos comparados con otras variedades liberadas para secano, por loque se ubica comoexcelente opción parasiembras en todos los ambientes de producción de trigo de temporal en México. Altiplano F2007 fue obtenida por hibridación y selección, utilizando el método de familias masivas.

La cruza identificada como TC980280 se realizó en el Campo Experimental Valle de México (CEVAMEX) ubicado en Chapingo, Estado de México (19³ 31' LN y 2240 msnm) en 1999 y su $\mathrm{F}_{1}$ se avanzó masivamente. En la generación $\mathrm{F}_{2}$ fue seleccionada la planta número 13 (13C) en el CEVAMEX; se realizó selección interfamiliar en las generaciones $\mathrm{F}_{3}$ en el Campo Experimental El Bajío (CEBAJ), ubicado en Celaya, Guanajuato $\left(20^{\circ} 32^{\prime}\right.$ latitudnortey $\left.1752 \mathrm{~m}\right), \mathrm{F}_{4}$ en elCEVAMEX $\mathrm{y}_{5}$ en el CEBAJ; en la $\mathrm{F}_{6}$ se seleccionó en el CEVAMEX la planta individual número $6(6 \mathrm{C})$, y en $\mathrm{la}_{7}$ en el CEBAJ se cosechó masivamente la línea que dio origen a la variedad. La genealogía es GAVIA/ROM/4/PINO/IMU//ROM/3/ PVN/PC y su pedigrí TC980280-13C-0R-0C-0R-6C-0R.

Altiplano F2007 fue evaluada de 2005 a 2012 en 121 localidades de los estados de Oaxaca, Puebla, Tlaxcala, Hidalgo, Estado de México, Guanajuato, Michoacán, Jalisco, Aguascalientes, Zacatecas, Durangoy Chihuahua, como parte de los ensayos nacionales de trigo harinero de temporal. Es de hábito de crecimiento de primavera, de porte semi-erecto al amacollamiento y posee tallos tolerantes al acame; a inicios del espigamiento tiene una frecuencia alta de plantas con hoja bandera recurvada, de espigamiento uniforme y espigas con poca serosidad durante el llenado de grano; en madurez sus espigas son de color claro, piramidales, laxas y de posición ligeramente curvada; su grano es mediano, blanco aámbary de consistencia dura; su altura de planta es de $90 \mathrm{~cm}$ en promedio; sin embargo, en condiciones de sequía $(150 \mathrm{~mm})$ presentó alturas de $55 \mathrm{~cm}$ y en lugares lluviosos $(750 \mathrm{~mm})$ de $115 \mathrm{~cm}$. Ésta variedad se clasifica de ciclo tardío, semejante a Rebeca F2000; en promedio el número de días a floración y madurez es de 86 y 153 días, respectivamente.

Esta variedad registró lecturas de infección de roya de la hoja (Pucciniatriticina) de 0R (resistente)a 10MR (moderadamente resistente), tipo de reacción que iguala las reacciones de las mejores variedades testigo (Tlaxcala F2000 y Romoga F96), pero con menor porcentaje de infección. Para roya amarilla (Puccinia striiformis fsp.tritici)es resistenteamoderadamente resistente (0R a $15 \mathrm{MR})$ a las razas presentes hasta el ciclo primavera- verano 2012 en temporal, de tal manera que ésta variedad mostró los mayores niveles de resistencia a roya
The crosses identified as TC980280 was conducted in the Experimental Field Mexico Valley (CEVAMEX) located in Chapingo, State of Mexico (19 31' LN and $2240 \mathrm{~m}$ ) in 1999 and has progressed massively $F_{1}$. In the $F_{2}$ generation was selected plant number 13 (13C) in the CEVAMEX;family selection was performed in generations $\mathrm{F}_{3}$ in the Experimental Field El Bajío (CEBAJ) located in Celaya, Guanajuato, $\left(20^{\circ} 32^{\prime}\right.$ north latitude and $\left.1752 \mathrm{~m}\right), \mathrm{F}_{4}$ and $\mathrm{F}_{5}$ in CEVAMEX of CEBAJ, in the $\mathrm{F}_{6}$ was selected in the individual plant CEVAMEX No. $6(6 \mathrm{C})$, and the $\mathrm{F}_{7}$ in CEBAJ massively reaped the line gave rise to the variety. Genealogy is GAVIA/ROM/4/PINO/IMU//ROM/3/PVN/ PC and pedigree TC980280-13C-0R-0C-0R-6C-0R.

Altiplano F2007 was evaluated from 2005 to 2012 in 121 locationsintheStatesofOaxaca,Puebla, Tlaxcala,Hidalgo,State of Mexico, Guanajuato, Michoacán, Jalisco, Aguascalientes, Zacatecas, Durango and Chihuahua, as part of national trials of rainfed bread wheat. It's growth habit of spring, semi-erect to tillering demeanor and possesses tolerant to lodging stalks; early tasseling has a high frequency of plants with flag leaf recurved, tasseling uniform and spikes with little serosity during grain filling, in theirmaturity are light spikes, pyramidal, loose and slightly colored curved position, its grain is medium amber and white hard consistency, its plant height is $90 \mathrm{~cm}$ on average, but under drought $(150 \mathrm{~mm})$ had heights of $55 \mathrm{~cm}$ and rainy places $(750 \mathrm{~mm})$ of $115 \mathrm{~cm}$. This variety is classified as late cycle, like Rebeca F2000, on average the number of days to flowering and maturity is 86 and 153 days, respectively.

This variety of infection recorded readings of leaf rust (Puccinia triticina) of 0R (resistant) to $10 \mathrm{MR}$ (moderately resistant), reaction type reactions equals the best check varieties (Tlaxcala F2000 and Romoga F96), but with lower percentage of infection. For yellow rust (Puccinia striiformis $\mathrm{f}$ sp. Tritici) is resistant to moderately resistant (OR $15 \mathrm{MR})$ breeds present until the spring-summer season 2012 in time, so that this variety showed the highest levels of rust resistance Yellow, both the foliage and the tang(Box 1). Forfoliardiseases complex where leaf blight (Cochleobolus sativum), tan spot (Phyrenophoratritici-repentis), leaf spot(Septoriatritici), leaf spot (Fusarium nivale) and glume blight were presented ( $S$. nodorum), Altiplano F2007 equaled Rebeca F2000 resistance, which was the most resistant of the control varieties.

In Altiplano F2007 has Lr46 resistance gene located on chromosome 1BL first identified in the detected range Pavon F76 (Singh et al., 1998) and confers resistance besides leaf rust, resistance to other foliar diseases including yellow rust 
amarilla, tanto en el follaje como en la espiga (Cuadro 1). Para el complejo de enfermedades foliares, donde se presentaron tizón foliar (Cochleobolus sativum), mancha bronceada (Phyrenophora tritici-repentis), mancha foliar (Septoria tritici), mancha de la hoja (Fusariumnivale) y tizón de la gluma (S. nodorum), Altiplano F2007 igualó la resistencia de Rebeca F2000, que fue la más resistente de las variedades testigo.
(William et al., 2003; Singh et al., 2005; Rosewarne et al., 2006.). Altiplano F2007 is almost immune to breed MEX9611 having the formula of virulence/avirulence $\operatorname{Yr} 1,4,5,8$, $15,17 / 2,3,6,7,9,10,27$, based on the lines differentials arising from Avocet (Singh et al., 2000.) this indicates that this variety based stripe rust resistance in 3-4 genes in adult slow curl and additive effects (Singh et al., 2001.) plant.

\section{Cuadro 1. Respuesta a roya de la hoja, roya amarilla y enfermedades foliares de la variedad Altiplano F2007 y variedades testigo evaluadas en primavera-verano 2005 a 2012.}

Table 1. Response to leaf rust, yellow rust and leaf diseases of Altiplano F2007 variety and control varieties evaluated in spring-summer 2005-2012.

\begin{tabular}{lllll}
\hline Variedad & Roya amarilla follaje & Roya amarilla espiga (\%) & Roya hoja & Foliares \\
\hline Altiplano F2007 & TR a 15MR & 5 & 0R a 10MR & $7 / 30(\mathrm{~T})$ \\
Triunfo F2004 & 20MS a 50MS & 20 & 0R a 50S & $7 / 50(\mathrm{MS})$ \\
Rebeca F2000 & TR a 40MS & 20 & 15MS a 70S & $7 / 30(\mathrm{~T})$ \\
Tlaxcala F2000 & 10MR a 40MS & 15 & 0R a 30MR & $7 / 50(\mathrm{MS})$ \\
Náhuatl F2000 & 0R a 60S & 20 & 0R a 80S & $7 / 60(\mathrm{MS})$ \\
Juchi F2000 & 15MR a 60MS & 30 & 0R a 70S & $7 / 40(\mathrm{~T})$ \\
Batán F96 & 40MS a 60S & 70 & 0R a 70S & $7 / 50(\mathrm{MS})$ \\
Romoga F96 & 0R a 50MS & 15 & 0R a 30MR & $7 / 70(\mathrm{~S})$ \\
Temporalera M87 & 40MS a 70S & 10 & 0R a 100S & $7 / 50(\mathrm{MS})$ \\
Gálvez M87 & 40MS a 80S & 0R a 100S & $7 / 80(\mathrm{~S})$ \\
\hline
\end{tabular}

$\mathrm{TR}=$ trazas $\mathrm{MR}=$ moderadamente resistente; $\mathrm{MS}=$ moderadamente susceptible; $\mathrm{S}=$ susceptible $; \mathrm{T}=$ tolerante.

En Altiplano F2007 se detectó la presencia del gen de resistencia Lr46 localizado en el cromosoma 1BLidentificado primeramente en la variedad Pavón F76 (Singh et al., 1998) y confiere, además de resistencia a la roya de la hoja, resistenciaa otras enfermedades foliares incluyendo roya amarilla(William et al., 2003; Singh et al., 2005; Rosewarne et al., 2006). Altiplano F2007 es casi inmune a la raza MEX96-11 que tiene la fórmula de avirulencia/virulencia $Y r 1,4,5,8,15,17 / 2,3$, $6,7,9,10,27$, basado en las líneas diferenciales derivadas de Avocet(Singh et al., 2000); lo anterior indica que esta variedad basa su resistencia a roya lineal en 3 a 4 genes de enrollamiento lento en planta adultay de efectos aditivos (Singh et al., 2001).

Altiplano F2007 posee Yr29 (William et al., 2003) que es un gen que confiere resistencia a todas las razas del patógeno, pero no confiere inmunidad. También posee $Y r 30$ que está ligado al gene $S r 2$ que confiere resistencia a la roya del tallo, inclusive a $U g 99$ (Singh et al., 2005). Posee otro gene de resistencia por designar en planta adulta y que se encuentra localizado en el cromosoma 7BL, lo que se determinó mediante el uso de marcadores moleculares (Herrera-Foessel et al., 2009).

Se evaluaron las características agronómicas de Altiplano F2007 comparada con variedades de alto rendimiento como Rebeca F2000, Triunfo F2004, Tlaxcala F2000,
Altiplano F2007 has R29 (William et al., 2003) which is a gene that confers resistance to all races of the pathogen, but does not confer immunity. It also has R30 that is linked to $\mathrm{Sr} 2$ gene conferring resistance to stem rust, including Ug99 (Singh et al., 2005). It has another resistance gene in adult plant and designate which is located on chromosome 7BL, which was determined by the use of molecular markers (Herrera-Foessel et al., 2009).

Agronomic traits of Altiplano F2007 compared to high yielding varieties like Rebeca F2000, Triunfo F2004, Tlaxcala F2000, Romoga F96 and Náhuatl F2000 were evaluated, and the low yield and Batán F96, Juchi F2000, Gálvez M87 and Temporalera M87, the testing was conducted in 121 sites classified according to Villaseñor and Espitia (2000), in critical environments $(<300 \mathrm{~mm})$ with lower yields to $2.5 \mathrm{t} \mathrm{ha}^{-1}$, intermediate environments $(300$ to $600 \mathrm{~mm}$ ) with yields of 2.5 to $3.5 \mathrm{tha}^{-1}$ and in favorable environments (>600 mm ) with higher yields to $3.5 \mathrm{t} \mathrm{ha}^{-1}$ (Table 2). Altiplano F2007 on average outperformed the varieties Rebeca F2000 and Triunfo F2004, 6\% to Romoga F96 and Tlaxcala F2000 with $11 \%$, and Náhuatl F2000 with $15 \%$, at the low-yielding varieties exceeded $20 \%$ (Juchi F2000) to 24\% (Batán F96). Altiplano F2007 outperformed all the three control varieties in production environments, 
Romoga F96 y Náhuatl F2000; y con las de bajo rendimiento como Batán F96, Juchi F2000, Gálvez M87 y Temporalera M87; las pruebas se realizaron en 121 sitios clasificados de acuerdo con Villaseñor y Espitia (2000), en ambientes críticos $(<300 \mathrm{~mm})$ con rendimientos menores a $2.5 \mathrm{t} \mathrm{ha}^{-1}$; ambientes intermedios ( $300 \mathrm{a} 600 \mathrm{~mm}$ ) con rendimientos de 2.5 a $3.5 \mathrm{t}$ $\mathrm{ha}^{-1} \mathrm{y}$ en ambientes favorables $(>600 \mathrm{~mm})$ con rendimientos mayores a 3.5 tha $^{-1}$ (Cuadro 2). Altiplano F2007 en promedio superó a la variedades RebecaF2000y Triunfo F2004 con 6\%, a Tlaxcala F2000 y Romoga F96 con 11\%, y a Náhuatl F2000 con $15 \%$; a las variedades de bajo rendimiento las superó entre 20\% (Juchi F2000) a 24\% (Batán F96). Altiplano F2007 superó a todas las variedades testigo en los tres ambientes de producción; en los ambientes intermedios fue mayor su ventaja y en los ambientes críticos se redujo ligeramente con respecto a las variedades precoces Tlaxcala F2000 y Gálvez M87. De acuerdo con el análisis de los parámetros de estabilidad de Eberhart y Russell (1966), los coeficientes de regresión de Altiplano F2007 y Tlaxcala F2000 fueron los mayores $\left(\beta_{1}=\right.$ 1.3), lo que determina que estás variedades son las que tienden a responder mejor a medida que se mejora el ambiente de producción; Tlaxcala F2000 se comportó como una variedad estable, de acuerdo ala maneracomo fue descrita por Villaseñor et al. (2005); Altiplano mostró semejante comportamiento, aunque la ventaja de esta última sobre Tlaxcala F2000 es su mayor potencial de rendimiento. in intermediate environments was greater your advantage in critical environments and decreased slightly compared to the early varieties Tlaxcala F2000 and Gálvez M87. According to the analysis of the stability parameters of Eberhart and Russell (1966), the regression coefficients of Altiplano F2007 and Tlaxcala F2000 were older $\left(\beta_{1}=1.3\right)$, which determines which varieties are those that are tend to respond better as it improves the production environment; Tlaxcala F2000 behaved as a stable variety, according to the way it was described by Villaseñor et al. (2005); Altiplano showed similar behavior, although the advantage of the latter on Tlaxcala F2000 is its higher yield potential.

Altiplano F2007 is characterized by its high test weight grain, strong gluten and good bread volume. Grain hardness is a basic parameter for classifying wheat, feature commonly associated with a higher protein content and gluten quality (Zeleny, 1978). According to Pearl index (PI= 44\%), Altiplano F2007 is classified as semi-hard wheat, a characteristic that makes it suitable for rainfed.

Presented a test weight of $76 \mathrm{~kg} / \mathrm{hl}$ and protein content in flour $11.8 \%$, surpassing the control varieties in the two variables. Its sedimentation rate was $53 \mathrm{~mL}$ and the value of its behavior was $422 \times 10^{-4} \mathrm{~J}$, figures that correspond to a strong gluten wheat (group 1). The toughness value was 1.2

Cuadro 2. Comparación del rendimiento de grano y características agronómicas deAltiplano F2007 (Alt) y nueve variedades testigo en promedio de 121 evaluaciones en los ambientes de producción favorables, intermedios y críticos. Primavera- verano-2005 a 2012.

Table 2. Comparison of grain yield and agronomic traits of Altiplano F2007 (Alt) and nine control varieties averaged 121 reviews in environments favorable, intermediate and critical production. Spring-Summer 2005 to 2012.

\begin{tabular}{|c|c|c|c|c|c|c|c|c|c|c|c|c|c|c|c|c|c|c|}
\hline \multirow[b]{2}{*}{ Variedad } & \multicolumn{4}{|c|}{$\begin{array}{l}\text { Comportamiento } \\
\text { general (121) }\end{array}$} & \multicolumn{4}{|c|}{$\begin{array}{c}\text { Ambientes } \\
\text { favorables (29) }\end{array}$} & & \multicolumn{4}{|c|}{$\begin{array}{c}\text { Ambientes } \\
\text { intermedios (40) }\end{array}$} & \multicolumn{5}{|c|}{$\begin{array}{l}\text { Ambientes } \\
\text { críticos (52) }\end{array}$} \\
\hline & $\mathrm{kg} \mathrm{ha}^{-1}$ & $\begin{array}{l}(\%) \\
\text { Alt }\end{array}$ & DF DM & $\mathrm{AP}$ & $\mathrm{kg} \mathrm{ha}^{-1}$ & $\begin{array}{r}(\%) \\
\text { Alt }\end{array}$ & DF & DM & & $\mathrm{kg} \mathrm{ha}^{-1}$ & $\begin{array}{l}(\%) \\
\text { Alt }\end{array}$ & & $\mathrm{DM} A$ & $\mathrm{rob}$ & $\begin{array}{r}{ }^{1}(\%) \\
\text { Alt }\end{array}$ & & & \\
\hline Altiplano F2007 & 3173 & - & 64114 & 90 & 4842 & - & 66 & 123 & 100 & 3585 & - & 65 & 11496 & 1933 & - & 62 & 108 & 80 \\
\hline Rebeca F2000 & 2979 & -6 & 66116 & 83 & 4648 & -4 & 69 & 126 & 91 & 3341 & -7 & 67 & 11889 & 1774 & -8 & 64 & 110 & 74 \\
\hline Triunfo F2004 & 2978 & -6 & 61112 & 80 & 4561 & -6 & 64 & 121 & 87 & 3265 & -9 & 62 & 11385 & 1805 & -7 & 59 & 105 & 72 \\
\hline Tlaxcala F2000 & 2837 & -11 & 59110 & 79 & 4240 & -12 & 61 & 118 & 87 & 3240 & -10 & 60 & 11185 & 1790 & -8 & 57 & 104 & 71 \\
\hline Romoga F96 & 2809 & -11 & 61111 & 79 & 4374 & -10 & 64 & 120 & 87 & 3086 & -14 & 62 & 11284 & 1727 & -11 & 60 & 105 & 70 \\
\hline 2000 & 2710 & -15 & 59107 & 81 & 4302 & -11 & 62 & 117 & 91 & 2917 & -19 & 59 & 10987 & 1669 & -14 & 57 & 101 & 71 \\
\hline Juchi l & 2554 & -20 & 60111 & 80 & 3915 & -19 & 63 & 120 & 88 & 2791 & -22 & 61 & 11286 & 1598 & -17 & 58 & 105 & 71 \\
\hline Temporalera M87 & 2491 & -21 & 61111 & 85 & 3876 & -20 & 64 & 121 & 94 & 2635 & -26 & 62 & 11391 & 1600 & -17 & 59 & 105 & 74 \\
\hline Gálvez M87 & 2480 & -22 & 55106 & 77 & 3687 & -24 & 58 & 115 & 85 & 2677 & -25 & 56 & 10882 & 1643 & -15 & 53 & 100 & 68 \\
\hline Batán F96 & 2399 & -24 & 61110 & 78 & 3783 & -22 & 64 & 119 & 86 & 2533 & -29 & 62 & 11183 & 1521 & -21 & 60 & 104 & 70 \\
\hline Tukey (5\%) & 232 & & 0.51 .2 & 1.6 & 326 & & 1 & 1.4 & 3 & 278 & & 1 & 2.83 & 168 & & 1 & 1.8 & 2 \\
\hline
\end{tabular}

$\mathrm{DF}=$ días a floración; $\mathrm{DM}=$ días a madurez; $\mathrm{AP}=$ altura de planta. 
Altiplano F2007 se caracteriza por su grano de alto peso hectolítrico, de gluten fuerte y con buen volumen de pan. La dureza de grano es un parámetro básico para clasificar al trigo, característica comúnmente asociada a un mayor contenido de proteína y calidad de gluten (Zeleny, 1978). De acuerdo al índice de perlado (IP=44\%), Altiplano F2007 se clasifica dentro de los trigos semi-duros, característica que la hace adecuada para siembras de temporal.

Presentó peso hectolítrico de $76 \mathrm{~kg} / \mathrm{hL}$ y un contenido de proteína en la harina de $11.8 \%$, superando a las variedades testigo en las dos variables. Su índice de sedimentación fue de $53 \mathrm{~mL}$ y el valor del comportamiento alveográfico de su harina fue $422 \times 10^{-4} \mathrm{~J}$, cifras que corresponden a un trigo de gluten fuerte (grupo 1). Su valor de tenacidad del gluten fue 1.2, lo que junto con el valor de su fuerza lo clasifican como un trigo de gluten fuerte balanceado, características apropiadas principalmente para la panificación mecanizada para hacer pan de caja o pan tipo bolillo; sin embargo, también se adecua para mezclas y corregir trigos de gluten suave o que sean tenaces.

Se recomienda sembrar Altiplano F2007 como la mejor opción en los tres ambientes de producción presentes en las áreas temporaleras de los estados de Oaxaca, Puebla, Tlaxcala, Hidalgo, Estado de México, Guanajuato, Michoacán, Jalisco, Aguascalientes, Zacatecas, Durango y Chihuahua. Ésta variedad responde bien en siembras de verano en alturas que van $1900 \mathrm{msnm}$ hasta $2900 \mathrm{msnm}$. Por su ciclo de cultivo intermedio a tardío, se siguiere sembrar en fechas tempranas a intermedias.

\section{Agradecimientos}

Los autores(a) agradecen al proyecto: "Sistema de mejoramiento genético para generar variedades resistentes a royas, de alto rendimiento y alta calidad para una producción sustentable de trigo en México" Núm. 146788. Fondo SAGARPA-CONACYT, por el financiamiento parcial de la presente investigación y su publicación.

\section{Literatura citada}

Eberhart, S. A. and Russell, W. A. 1966. Stability parameters for comparing varieties. Crop Sci. 6:36-40. gluten, which together with the value of his strength classified as a strong gluten wheat balanced, appropriate features mainly for mechanized bakery to make bread box or bread-type roll, but also suitable for blending and soft wheat gluten correct or are tenacious.

We recommend planting Altiplano F2007 as the best option in the three production environments present in the rainfed areas of the States of Oaxaca, Puebla, Tlaxcala, Hidalgo, State of Mexico, Guanajuato, Michoacán, Jalisco, Aguascalientes, Zacatecas, Durango and Chihuahua.

End of the English version

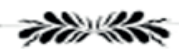

Fuente, P. J. L. 2008. ¿Quiénes somos? La industria molinera de trigo en México. Revista Canimolt 1(1):4-10.

Herrera-Foessel, S. A.; Singh, R. P.; Huerta-Espino, J. and Lagudah, E. S. 2009. Characterization and mapping of a gene component for durable leaf rust resistance in chromosome arm 7BL. Phytopathology 99:S53.

Moreno, G. R. y Villaseñor, M.H.E. 1993. Trigo de temporal.In: Márquez, S.F.(Ed.). Producción y genotecnia de plantas autogamas. AGT, Editor. México, D. F., México. 195-208 p.

Peña, B. R. J. 2006. Calidad de trigo. In: Ríos, R. S. A.; Solís, M.

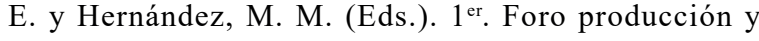
comercialización de trigo en Guanajuato. Memoria científica 2006. INIFAP-CEBAJ. 202 p.

Rosewarne, G. M.; Singh, R. P.; Huerta-Espino, J.; William, H. M.; Bouchet, S.; Cloutier, S.; McFadden, H. and Lagudah, E. S. 2006. Leaf tip necrosis, molecular markers and proteasome subunits associated with the slow rusting resistance genes $\mathrm{Lr} 46$ / Yr29. Theor. Appl. Genet. 112:500-508.

Servicio de Información Agroalimentaria y Pesquera SIAP. 2013. Estadísticas de producción agrícola. www.siap.gob.mx.

Singh, R. P.; Mujeeb-Kazi, A. and Huerta-Espino, J. 1998. Lr46 a gene conferring slow-rusting resistance to leaf rust in wheat. Phytopathology 88:890-894.

Singh, R. P.; Huerta-Espino, J. and Rajaram, S. 2000. Achieving nearimmunity toleafand striperusts in wheatby combining slow rusting resistance genes. Acta Fitopatológica Hungárica 35:133-139.

Singh, R. P.; Huerta-Espino, J. and William, M. 2001. Slow rusting genes based resistance to leaf and yellow rusts in wheat: genetics and breeding at CIMMYT. In: Eastwood, R.; Hollamby, R. G. T. and Gororo, N.(Eds.). Wheat breeding society of Australia. $10^{\text {th }}$ Assembly Proceedings. 16-21 September. Mildura, Australia.

Singh, R. P.; Huerta-Espino, J. and William, M. 2005. Genetics and breeding for durable resistance to leaf and stripe rust in wheat. Turk J. Agric. For. 29(2005):121-127.

Villaseñor, M. H. E. 2000. Importancia del trigo. In: Villaseñor, M. H. E. y Espitia, R. E. (Eds.). El trigo de temporal en México. Libro técnico Núm. 1. INIFAP-CIRCE-CEVAMEX. 7-22 pp.

Villaseñor,M.H.E.yEspitia,R.E.2000.Característicasdelasáreas productoras de trigo de temporal: problemática y condiciones de producción. In: Villaseñor,M.H.E.yEspitia, R.E. 2000.El trigo de temporal en México.Libro TécnicoNúm. 1.INIFAP-CIR-CENTRO.85-98 pp. 
Villaseñor, M. H. E.; Espitia, R. E.; Huerta, E. J.; María, R. A.; Osorio, A. L.; Aguirre, M.D. and Peña, B. J.2005. Registration of Tlaxcala F2000 wheat. Crop Sci. 45:425-426.

Villaseñor,M.H.E.;Limón, O.Ay Rodríguez, G. M.F.2008. Perspectivas de las siembras de trigo de temporal para reforzar la producción Nacional. Medio de difusión de la industria molinera de trigo. Revista Canimolt. 1:12-14.

Villaseñor, M. H. E.; Huerta, E. J.; Pérez, H. P.; Rodríguez, G. M. F.; Martínez, C. E.; Hortelano, S. R. R. y Espitia, R. E. 2009. La investigación de trigo en el Campo Experimental Valle de México: Historia y Aportaciones. Reseña Histórica 66 años al servicio de México 1943-2009. Campo Experimental Valle de México. Publicación especial Núm. 19-31 p.
Villaseñor, M. H. E.; Hortelano, S. R.; Martínez, C. E.; Mariscal, A. L. A.; Leyva M. S. G. y Huerta, E. J. 2012. Control químico de las enfermedades: una alternativa para la producción de trigo de temporal en Tlaxcala. Rev. Mex. Cienc. Agríc. 3:595-600.

William, M.; Singh, R. P.; Huerta-Espino, J.; Ortiz, I. S. and Hoisington, D. 2003. Molecular marker mapping of leaf rust resistance gene $L r 46$ and its association with stripe rust resistance gene $\mathrm{Yr} 29$ in wheat. Phytopathology 93:153-159.

Zeleny, L. 1978. Criteria of wheat quality. Chapter 2. In: wheat chemistry and technology. American Association of Cereal Chemists, St. Paul, Minnesota, USA. 19-49 pp. 